\title{
RADIOMETRIC CHRONOLOGY OF NEH-NAR GLACIER, KASHMIR
}

\author{
By V. N. NiJAmpurkar, N. BHANDARI, \\ (Physical Research Laboratory, Navrangpura, Ahmedabad 380 009, India) \\ C. P. Vohra, and V. KRISHNAN \\ (Glaciology Division, Geological Survey of India, Lucknow, India)
}

\begin{abstract}
Surface and core samples of Neh-nar Glacier in the Kashmir Valley have been analysed for the radionuclides ${ }^{32} \mathrm{Si},{ }^{210} \mathrm{~Pb},{ }^{40} \mathrm{~K}$, and ${ }^{137} \mathrm{Cs}$. The lateral and vertical profiles (at an altitude of about $4140 \mathrm{~m}$ ) reveal:

(1) ${ }^{32} \mathrm{Si}$ activity decreasing slowly from the accumulation zone to $4050 \mathrm{~m}$ altitude and then abruptly towards the snout.

(2) Five zones of alternating high and low ${ }^{210} \mathrm{~Pb}$ activity in the surface samples.

(3) An horizon at between 2 and $3 \mathrm{~m}$ depth containing ${ }^{210} \mathrm{~Pb}$ activity above natural levels. This horizon is also associated with ${ }^{137} \mathrm{Cs}$ and a maximum in total $\beta$ activity.

The ice samples have been dated on the basis of a simplified two-component model, the "fresh" contribution determined by ${ }^{210} \mathrm{~Pb}$ and the old component by ${ }^{32} \mathrm{Si}$. The following conclusions can be drawn from these
\end{abstract} observations:

(1) The model age of the snout ice is $c .850$ years.

(2) The average rate of ice movement in the lower glacier is about $2 \mathrm{~m} /$ year, which compares well with the annual movement rate of $2.65 \mathrm{~m} /$ year observed since 1974 .

RÉSUMÉ. Chronologie du Neh-nar Glacier, Kashmir, par radiométrie. Des échantillons prélevés en surface et par carottage dans le Neh-nar Glacier, dans la vallée du Kashmir, ont été analysés pour leur teneur en radionucléide ${ }^{32} \mathrm{Si},{ }^{210} \mathrm{~Pb},{ }^{40} \mathrm{~K}$, et ${ }^{137} \mathrm{Cs}$. Les profils latéraux et verticaux (à une altitude d'environ $4140 \mathrm{~m}$ ) révèlent:

(1) Une activité du ${ }^{32} \mathrm{Si}$ décroissant lentement depuis la zone d'accumulation jusqu'à l'altitude de $4050 \mathrm{~m}$ puis s'effondrant brusquement jusqu'à la langue.

(2) Cinq zones présentant alternativement des activités fortes et faibles en ${ }^{210} \mathrm{~Pb}$ dans les échantillons de surface.

(3) Un horizon entre 2 et $3 \mathrm{~m}$ de profondeur contenant une activité en ${ }^{210} \mathrm{~Pb}$ supérieure aux niveaux naturels. Cet horizon est également associè à du ${ }^{137} \mathrm{Cs}$ et à un maximum d'activité beta totale.

En se basant sur un modèle simplifié à deux composantes, ou la contribution de la glace "fraîche" est déterminée par ${ }^{210} \mathrm{~Pb}$ et la composante ancienne par ${ }^{32} \mathrm{Si}$, on a pu dater les échantillons de glace. De ces observations on a putirer les conclusions suivantes:

(1) L'âge théorique de la glace du front est d'environ 850 ans.

(2) La vitesse moyenne de la glace dans le bas du glacier est d'environ $2 \mathrm{~m}$ par an, ce qui cadre bien avec la vitesse réelle de $2,65 \mathrm{~m}$ /an observée depuis 1974 .

ZUSAMMENFASSUNG. Radiometrische Chronologie des Neh-nar Glacier, Kashmir. Proben von der Oberfläche und aus Bohrkernen des Neh-nar Glacier im Kashmir-Tal wurden auf die Radionukleide ${ }^{32} \mathrm{Si},{ }^{210} \mathrm{~Pb}$, ${ }^{40} \mathrm{~K}$, und ${ }^{137} \mathrm{Cs}$ untersucht. Die Horizontal- und Vertikalprofile (in einer Höhe von etwa $4140 \mathrm{~m}$ ) geben folgendes Bild:

(1) Die ${ }^{32} \mathrm{Si}$-Aktivität nimmt erst langsam, dann abrupt von der Akkumulationszone in $4050 \mathrm{~m}$ Höhe zur Zunge hin ab.

(2) Die Oberflächenproben weisen 5 Zonen von wechselweise hoher und niedriger ${ }^{210} \mathrm{~Pb}$-Aktivität aus.

(3) Ein Horizont in 2 bis $3 \mathrm{~m}$ Tiefe weist eine ${ }^{210} \mathrm{~Pb}$-Aktivität über normalem Niveau auf. Dieser Horizont ist auch mit ${ }^{137} \mathrm{Cs}$ und einem Maximum in der Gesamt-Beta-A ktivität verbunden.

Auf der Grundlage eines Zwei-Komponenten-Modells, nämlich des "frischen" Beitrags durch ${ }^{210} \mathrm{~Pb}$ und der alten Komponente durch ${ }^{32} \mathrm{Si}$, wurden die Eisproben datiert. Aus diesen Beobachtungen können folgende Schlüsse gezogen werden:

(1) Das "Modell"-Alter des Zungeneises beträgt etwa 850 Jahre.

(2) Die mittlere Jahresbewegung des Eises im unteren Teil des Gletschers ist schätzungsweise $2 \mathrm{~m}$ pro Jahr, was gut mit dem seit 1974 beobachteten Wert von 2,65 m pro Jahr zusammenstimmt.

\section{INTRODUCTION}

Neh-nar Glacier is located in the northern Himalaya at lat. $34^{\circ} 09^{\prime} 30^{\prime \prime}$ N., long. $75^{\circ} 31^{\prime} \mathrm{E}$. 
It is part of the catchment of the Sind River, which is a tributary of the Jhelum in the Kashmir Valley. Figure 1 shows the location of this basin. Neh-nar is a small valley-type glacier enclosed between two ridges, trending in a direction N. $70^{\circ}$ W.-S. $70^{\circ}$ E. and rising to $5376 \mathrm{~m}$ and $5256 \mathrm{~m}$, respectively. It is $3.5 \mathrm{~km}$ long and about $350 \mathrm{~m}$ wide. Its head is $4925 \mathrm{~m}$ high and the snout is $3920 \mathrm{~m}$ above sea-level.

The glacier is predominantly avalanche-fed. Only a small area near its head, which is separated from the rest of the glacier by an ice fall, is fed largely by snow-fall and drift snow. The avalanches sweep down from the steep slopes, which are almost $1000 \mathrm{~m}$ high, on to the glacier, creating a number of large accumulation zones on its flanks. These, though present on both flanks, are more common on the southern side. The pattern of accumulation on Neh-nar is therefore peculiar, although this type of glacier is common in the Himalaya. Two tributaries descending steeply from the south-eastern side also join the glacier in its lower half. The lower part of the glacier slope is gentler than its upper part (Fig. 2). The main glacier flows in a direction between $\mathrm{N} .65^{\circ} \mathrm{W}$. and $\mathrm{N} .40^{\circ} \mathrm{W}$. The thickness of ice, estimated from electrical resistivity surveys, ranges between $14 \mathrm{~m}$ near the snout to $139 \mathrm{~m}$ in the upper reaches of the ablation zone.

Neh-nar is the westernmost glacier of the Panjatarni group (Fig. 1). It has been extensively studied since 1974 by the Glaciology Division of the Geological Survey of India (Vohra and others, unpublished). They have discussed morphology, mass balance, glacier movement, and water discharge, and detailed results of the 1975 and 1976 expeditions can be found in the GSI reports (Vohra and others, unpublished).

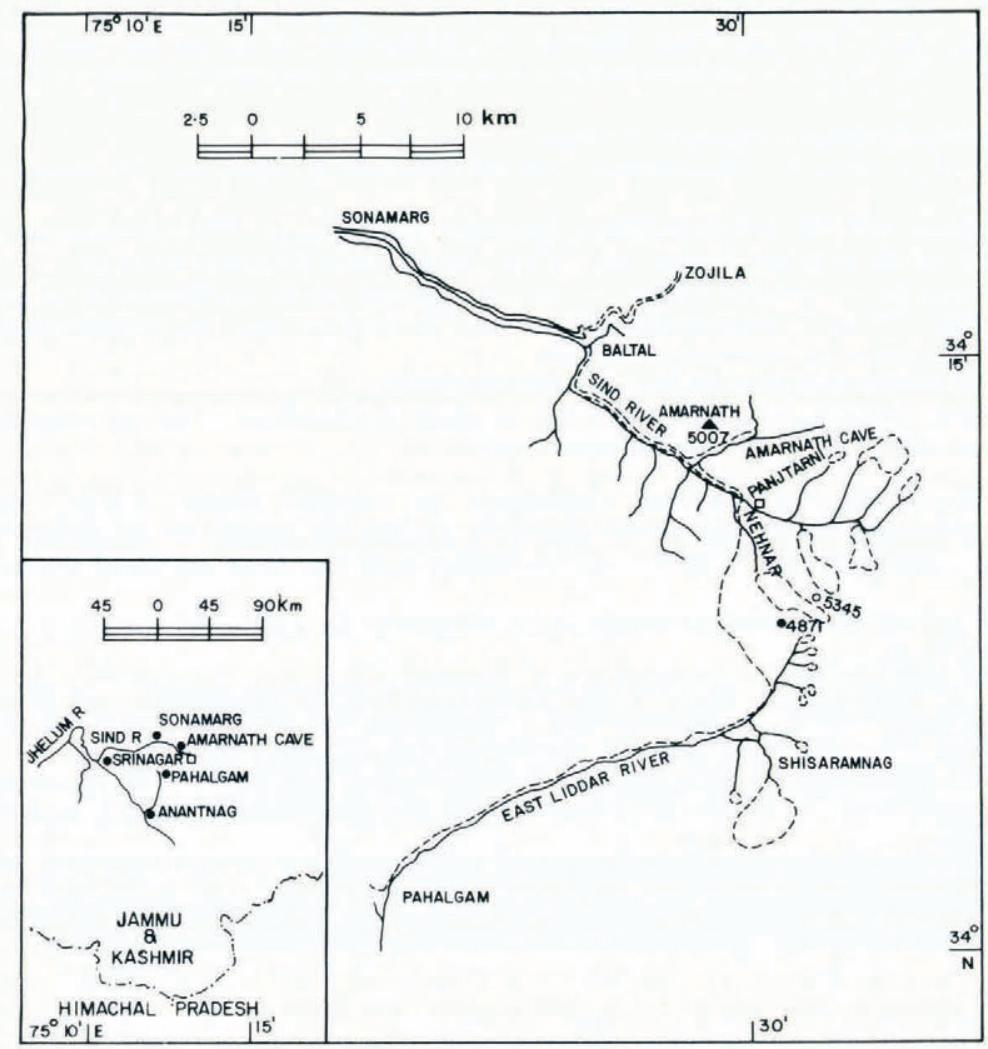

Fig. 1. Location of Neh-nar Glacier in the Sind catchment area. 


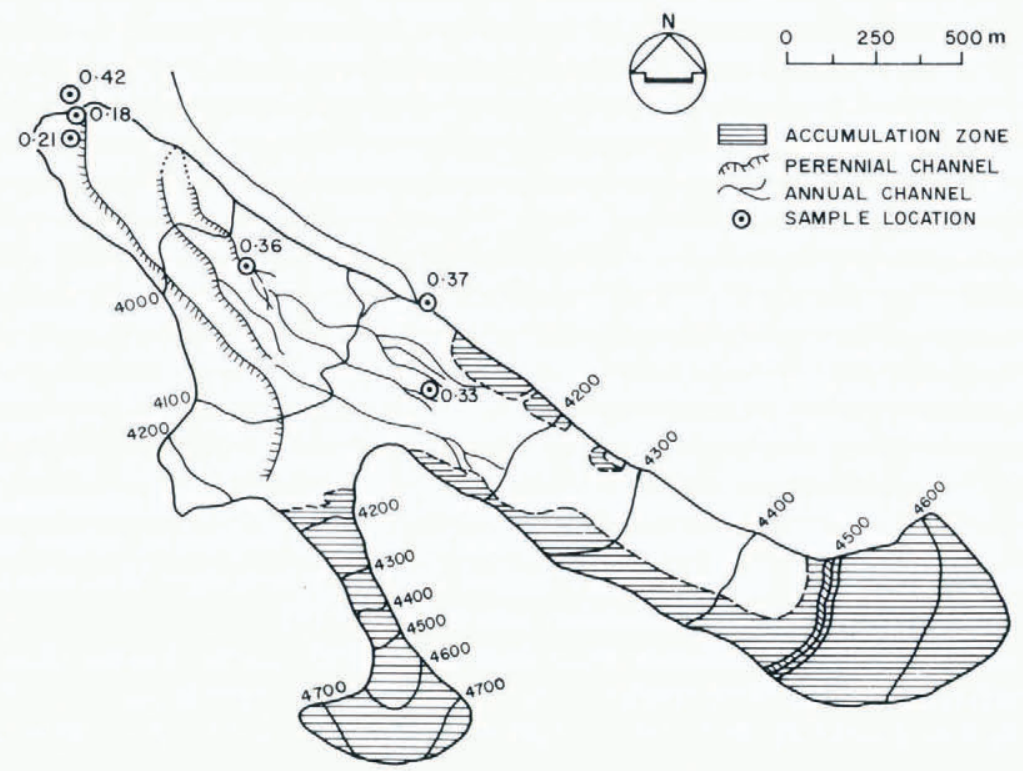

Fig. 2. Distribution of ${ }^{32}$ Si activity (dpm/ton) in surface samples of Neh-nar Glacier.

Geologically, the Neh-nar area contains extensive dolomite-limestone formations. Geomorphological studies indicate that two lateral moraine ridges flank the glacier, both merging with the terminal moraine, thereby damming the glacier melt water into a pro-glacial lake. This lake drains through a deep channel cut in the terminal moraine. About $20000 \mathrm{~m}^{2}$ of the terminal parts of this glacier are buried under $8-10 \mathrm{~m}$ of fluvio-glacial sediments deposited in this lake (Vohra and others, unpublished).

These sediments and the existence of two or three lake terraces on the terminal moraine, $20 \mathrm{~m}$ higher than the present lake surface, indicate that the present lake occupied a much larger area in the past and covered part of the glacier (Vohra and others, unpublished).

The glacier is both receding and thinning under the influence of a series of negative massbalance years. The ablation is strongly seasonal and the mass-balance studies carried out by fixing wooden stakes in the summer months (August-September 1975) indicate an ablation varying from $9.97 \mathrm{~cm}$ (September) to $47.81 \mathrm{~cm}$ (August) of water equivalent. Glacier surfacemovement studies indicate a maximum movement of $42 \mathrm{~m} /$ year near an altitude of $4200 \mathrm{~m}$, decreasing to $2.65 \mathrm{~m} /$ year near the terminus. At the terminus itself, the ice is practically static. The velocity gradually decreases down-slope, but more rapidly between $4200 \mathrm{~m}$ and $4100 \mathrm{~m}$ from $42 \mathrm{~m} /$ year to $15 \mathrm{~m} /$ year. The total area of the glacier is $1.68 \mathrm{~km}^{2}$, of which the accumulation area is $0.613 \mathrm{~km}^{2}$ and the ablation area is $1.068 \mathrm{~km}^{2}$ as measured during 1975-76.

The understanding of glacier history, the mass balance in the past, and the nature of the mass transfer that takes place between the accumulation area and the terminus are matters of great significance to glaciology. Besides, the estimation of the long-term mass balance of glaciers is of prime importance for the development of our water resources. Since annual estimates fluctuate significantly from year to year, and observations can at best cover only part of the year, we decided to use radiometric techniques to understand the long-term average behaviour of these glaciers. The results of these studies, which involve measurement of natural and man-made radioactive tracers, are reported here and discussed in relation to other studies carried out since 1975. 
A large number of radioactive tracers of natural and artificial origin occur in the environment. Of these, cosmogenic ${ }^{32} \mathrm{Si}$ with a half life of about 300 years is the best suited for glaciological studies because glacial phenomena occur in this time-scale (Lal and others, 1970; Clausen, 1973; Nijampurkar and Bhandari, unpublished). Among the natural radionuclides, ${ }^{210} \mathrm{~Pb}$ (half life of 22.3 years) offers the best choice (Goldberg, 1963; Crozaz and Langway, 1966). In addition, a large number of radionuclides have been introduced in the past few decades by nuclear explosions and these include ${ }^{90} \mathrm{Sr},{ }^{137} \mathrm{Cs}$, etc. The most dominant injection of these radionuclides occurred in the early 1960's as a result of nuclear tests carried out by the USA and USSR. Subsequently, France and China have also carried out several atmospheric nuclear tests but the amount of activity produced is small. Little reliable information is available on the Chinese nuclear tests but the best estimates are that they have been of 3 megaton yield or weaker and the most powerful tests known so far were carried out on 17 June 1967, 27 December 1968, 29 September 1969, 14 October 1970, 27 June 1973 and 17 November 1976 at about lat. $41^{\circ}$ N., long. $89^{\circ}$ E. (personal communication from G. S. Murty). No radionuclides from the underground peaceful nuclear explosion carried out by India in Rajasthan, which had a yield of about 20 kilotons, had been found to have leaked into the atmosphere (Ramanna, 1975) and they are well contained in the cavity (Bhandari and others, 1979).

Surface and core samples collected from Neh-nar Glacier during August-September 1977 have been analysed for these three components, ${ }^{32} \mathrm{Si},{ }^{210} \mathrm{~Pb}$, and bomb-produced ${ }^{137} \mathrm{Cs}$, discussed above. In addition, $\beta$ activity and dust content were also measured. The results are discussed here.

\section{EXPERIMENTAL TECHNIQUES AND SAMPLING METHODS}

Fifteen surface samples and eight core samples have been analysed for ${ }^{210} \mathrm{~Pb}$. All the core samples, each representing a depth interval of $1 \mathrm{~m}$, have also been analysed for ${ }^{137} \mathrm{Cs}$, ${ }^{40} \mathrm{~K}$, and total $\beta$ activity. ${ }^{32} \mathrm{Si}$ activity has been measured in six of the 15 surface samples. We describe here the sampling technique and then discuss the chemical and radiation counting methods employed for this analysis.

\section{Sampling techniques}

${ }^{32} \mathrm{Si}$ analysis requires a few tons of water. Six samples (NG-1 to NG-6), listed in Table I and ranging from 1.8 to 2.45 tons, were collected from selected locations including the subsidiary accumulation zone on the southern flank of the glacier (Fig. 2) and the snout. The sampling was carried out by removing surface ice and then digging small shallow trenches which drained into a pit. Admixture of small amounts of surface melt water in the sample cannot be ruled out in this procedure. The water was then transferred to a plastic or tarpaulin tank held in shape on an aluminium frame. Carriers were added for $\mathrm{Pb}\left(\right.$ as $\left.\mathrm{PbNO}_{3}\right)$ and $\mathrm{Si}\left(\right.$ as $\mathrm{Na}_{2} \mathrm{SiO}_{3}$ ) which were scavenged with iron hydroxide (about $3 \mathrm{~kg}$ ) in an ammoniacal medium following the procedure described earlier (Nijampurkar, unpublished). The volume of water was usually measured before collection in the tank and also during precipitation of $\mathrm{Fe}(\mathrm{OH})_{3}$. Aliquots of water before and after addition of carriers and after scavenging, and the amount of silica recovered, enabled us to determine the scavenging efficiency and silicon water equivalent. The overall efficiencies of silica extraction were around $75 \%$.

In addition to these samples, nine surface samples (Table IIb, 1-9), each of about $2 \mathrm{~kg}$, were collected from various locations on the glacier and these have been analysed for ${ }^{210} \mathrm{~Pb}$ (Fig. 3).

Core samples were collected by means of a thermal drill, about $5 \mathrm{~cm}$ in diameter, from an altitude of $4150 \mathrm{~m}$ in the ablation zone. Eight $1 \mathrm{~m}$ sections going down to $10 \mathrm{~m}$ were melted and stored in plastic bottles (Table III, 10-17). Although the possibility of cross contamination cannot be ruled out due to melting by the thermal drill, the contamination, if any, must be small. 


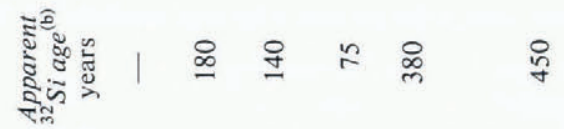

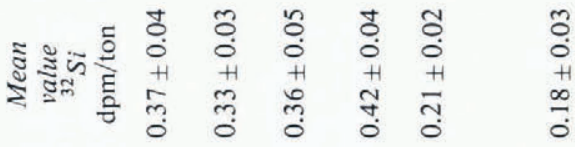

ชี

in $+0^{+}+0^{+1}$

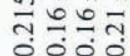

군

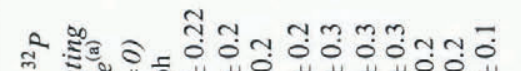

帘

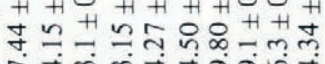

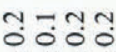

H hith

ชิำกำ

安

变

哇

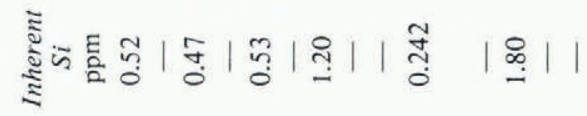

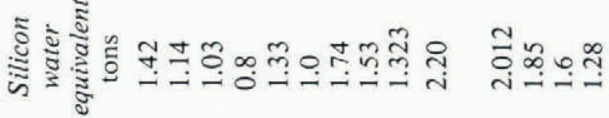

胥芯芯怘

竞

$\underline{z}$

嵌

学

突

\%

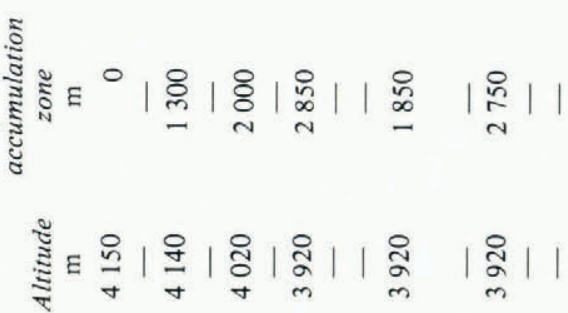

至

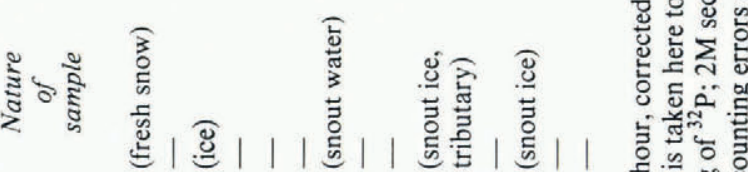

응

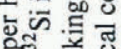

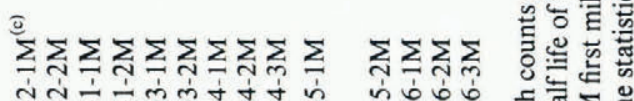

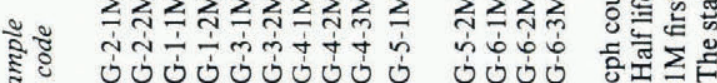


TABLE IIa. ${ }^{210} \mathrm{~Pb}$ ACTIVITY AND AGES OF THE SURFACE SAMPLES OF NEH-NAR GLACIER

$\begin{array}{lcccc}\text { Code } & \begin{array}{c}{ }^{210} \mathrm{~Pb} \text { water } \\ \text { equivalent } \\ \mathrm{kg}\end{array} & \begin{array}{c}{ }^{210} \text { Bi counting } \\ \text { rate, } t=0 \\ \mathrm{cpm}\end{array} & \begin{array}{c}{ }^{210} \mathrm{~Pb} \\ \mathrm{dpm} / \mathrm{kg}\end{array} & \begin{array}{c}\text { Apparent } \\ { }^{210} \text { Pb age } \\ \text { years }\end{array} \\ \text { NG-2 } & 85 \pm 8 & 80.8 \pm 0.2 & 4.2 \pm 0.5 & - \\ \text { NG-1 } & 140 \pm 20 & 34.9 \pm 1.5 & 2.4 \pm 0.2 & 35 \\ \text { NG-3 } & 208 & 94.4 \pm 1.5 & 2.1 \pm 0.1 & 40 \\ \text { NG-4 } & 115 & 28.8 \pm 0.3 & 1.12 \pm 0.1 & 60 \\ \text { NG-5 } & 106 & 25 \pm 0.06 & 1.27 \pm 0.1 & 55 \\ \text { NG-6 } & 180 & 56.6 \pm 0.12 & 1.75 \pm 0.1 & 45\end{array}$

For abbreviations, see Table I.

TABLE IIb. ${ }^{210} \mathrm{~Pb}$ ACTIVITY AND AGES OF SURFACE SAMPLES OF NEH-NAR GLACIER

$\begin{array}{cccccr}\text { Sample } & \begin{array}{c}\multicolumn{5}{c}{\begin{array}{c}{ }^{210} \text { Bi net } \\ \text { counting rate } \\ t=0\end{array}} \\ \text { Altitude } \\ \mathrm{m}\end{array} & \begin{array}{c}\text { Amount of } \\ \text { water } \\ \mathrm{kg}\end{array} & \begin{array}{c}{ }^{210} \mathrm{~Pb} \\ \mathrm{cpm}\end{array} & \begin{array}{c}\text { Apparent } \\ { }^{210} \mathrm{~Pb} \text { age }\end{array} \\ 1 & 4150 & 1.745 & 1.43 \pm 0.03 & 3.41 \pm 0.07 & \text { years } \\ 2 & 4380 & 2.26 & 2.59 \pm 0.06 & 4.7 \pm 0.11 & 27 \\ 3 & 4320 & 2.12 & \leqslant 0.17 & \leqslant 0.3 & 16 \\ 4 & 4203 & 1.9 & 0.29 \pm 0.03 & 0.6 \pm 0.06 & 80 \\ 5 & 4174 & 2.14 & \leqslant 0.45 & \leqslant 0.9 & \geqslant 70 \\ 6 & 4114 & 2.15 & 1.34 \pm 0.02 & 2.4 \pm 0.18 & 38 \\ 7 & 4089 & 2.14 & \leqslant 0.15 & \leqslant 0.6 & \geqslant 80 \\ 8 & 4030 & 2.29 & 0.237 \pm 0.014 & 0.4 \pm 0.02 & 95 \\ 9 & 3935 & 0.47 & \leqslant 0.22 & \leqslant 2.0 & \geqslant 44\end{array}$

Back in the laboratory, these samples were dried, counted for total $\beta$ activity, $\gamma$ activity and then processed for ${ }^{210} \mathrm{~Pb}$.

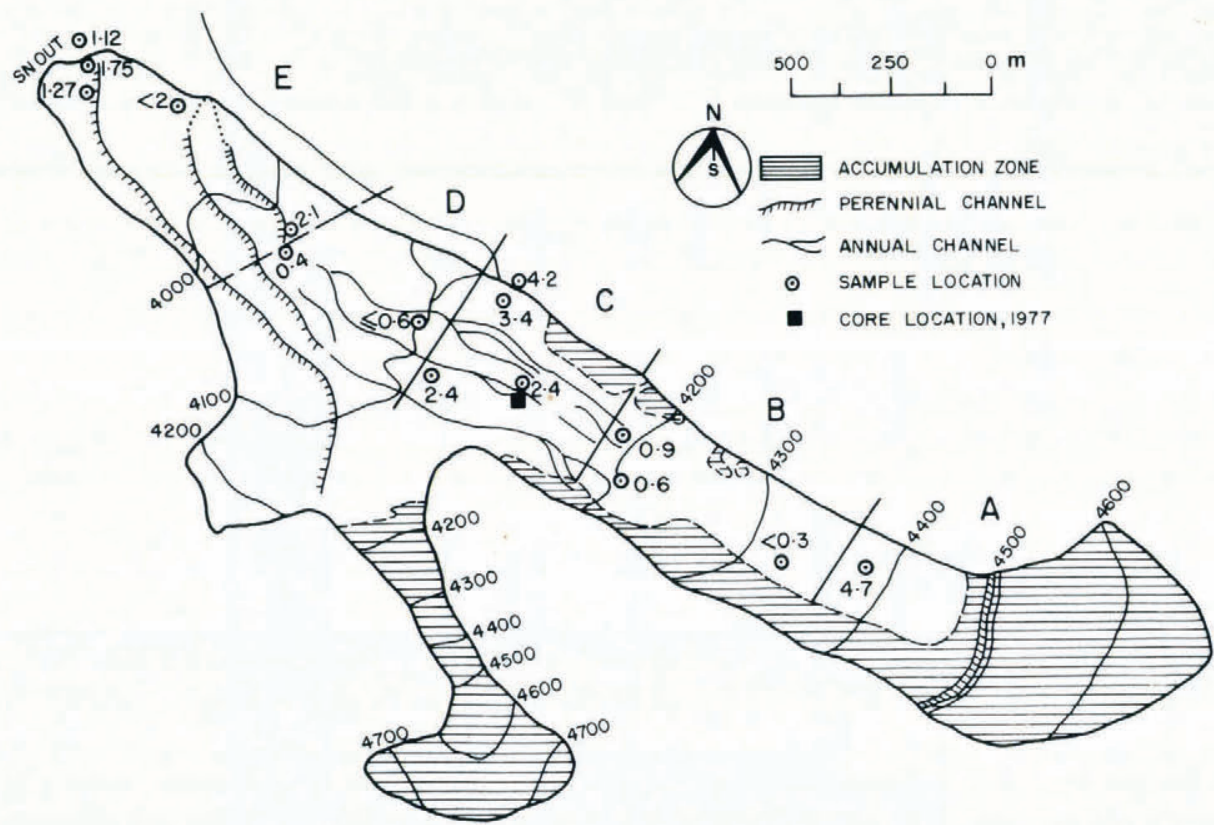

Fig. 3. Distribution of ${ }^{210} \mathrm{~Pb}$ activity $(\mathrm{dpm} / \mathrm{kg})$ in surface ice of Neh-nar Glacier. 
TABLE III. ${ }^{210} \mathrm{~Pb}$ ACTIVITY IN NEH-NAR GLACIER CORE SAMPLES

$\begin{array}{lcccc}\text { Sample } & \begin{array}{c}\text { Depth } \\ \mathrm{m}\end{array} & \begin{array}{c}\text { Amount of } \\ \text { water } \\ \mathrm{kg}\end{array} & \begin{array}{c}\text { Counting rate } \\ \mathrm{cpm}\end{array} & \begin{array}{c}{ }^{210} \mathrm{~Pb} \\ \mathrm{dpm} / \mathrm{kg}\end{array} \\ 10 & 0-1 & 1.35 & \leqslant 0.16 & \leqslant 0.4 \\ 10(\mathrm{R}) & 0-1 & 1.35 & 0.11 \pm 0.05 & 0.7 \pm 0.33 \\ 11 & 1-2 & 1.58 & 0.18 \pm 0.02 & 0.5 \pm 0.06 \\ 12 & 2-3 & 1.20 & 10.7 \pm 0.25 & 30.1 \pm 1.4 \\ 12(\mathrm{R}) & 2-3 & 1.20 & 8.2 \pm 0.2 & 35.6 \pm 0.90 \\ 13 & 3-4 & 0.54 & 0.77 \pm 0.09 & 4.7 \pm 0.05 \\ 14 & 4-5 & 0.61 & \sim 0.52 \pm 0.02 & 3.0 \pm 0.13 \\ 15 & 6-7 & 1.07 & 0.57 \pm 0.08 & 0.4 \\ 16 & 8-9 & 1.25 & \sim 0 & \leqslant 0.1 \\ 17 & 9-10 & 1.34 & \leqslant 0.31 & \leqslant 0.8\end{array}$

(R) The measurements on these samples were repeated by following growth of ${ }^{210} \mathrm{Bi}$ from ${ }^{210} \mathrm{~Pb}$.

\section{Chemical procedure and counting methods}

The chemical procedures adopted for ${ }^{32} \mathrm{Si}$ have been described in detail earlier (Nijampurkar, unpublished). Briefly, chemically pure silica was obtained from the hydroxide scavenge after repeated digestion with $\mathrm{HCl}$ and dehydration. This silica was purified by dissolution in $\mathrm{NaOH}$ and a phosphorus carrier was added. ${ }^{32} \mathrm{P}$, the daughter product of ${ }^{32} \mathrm{Si}$, was allowed to grow to a known degree of saturation and separated. It was radiochemically purified by ion exchange and selective chemical precipitation and ignited to $\mathrm{Mg}_{2} \mathrm{P}_{2} \mathrm{O}_{7}$. The procedure for ${ }^{210} \mathrm{~Pb}$ is similar to that adopted earlier (Bhandari, unpublished) for its determination in rain water. In short, after the addition of $\mathrm{Pb}$ and $\mathrm{Bi}$ carriers, iron was removed by ether extraction, and lead and bismuth were separated as sulphides. In most cases, ${ }^{210} \mathrm{~Pb}$ was estimated by following the decay of its daughter ${ }^{210} \mathrm{Bi}$. Bismuth was milked from the nitric acid solution of the sulphides at $\mathrm{pH} 3$ as the Dalzin complex (Navratna, unpublished). Bi was back extracted in $4 \mathrm{M} \mathrm{HNO}_{3}$ and ignited as bismuth phosphate. In other cases, lead was purified by dichromate precipitation, followed by ion-exchange separation and growth of ${ }^{210} \mathrm{Bi}$ was followed in the lead sulphate sample.

The counting procedures required that the activity of ${ }^{32} \mathrm{P}$ from ${ }^{32} \mathrm{Si}$ and of ${ }^{210} \mathrm{Bi}$ from ${ }^{210} \mathrm{~Pb}$ was followed for several half lives. Gas-flow, thin-window GM counters were used for this purpose. The background of the ${ }^{32} \mathrm{P}$ counters was around $2 \mathrm{cph}$ and of the ${ }^{210} \mathrm{Bi}$ counters was around $8 \mathrm{cph}$, which were quite stable over long periods of counting. The total $\beta$ activity was also measured in these counters (Table IV) after depositing the dried samples on $4 \mathrm{~cm}^{2}$ area source holders. Some of the samples were extremely hygroscopic and the values are not precise because of the possibility of the presence of some moisture (Table IV). The gamma counting was carried out on a $7.5 \mathrm{~cm}$ by $7.5 \mathrm{~cm}$ well-type $\mathrm{NaI}$ counter in anti-coincidence with a plastic scintillator (Table V).

\section{RESULTS}

The results on ${ }^{32} \mathrm{Si}$ in surface samples are given in Table I. Since the activity was small, between 2 and 9 counts per hour, all the samples were milked for ${ }^{32} \mathrm{P}$ a second time for confirmation. The activity in NG-4, which gave consistently higher values, and NG-6, the snout ice sample, which is quite crucial for estimating glacier age, was checked by a third milking. The replicate measurements are in agreement within $\pm 10 \%$. In the initial milkings, the natural phosphorus going through the silica-extraction procedure was not estimated but this was done subsequently and found to be rather small except in NG-5 (first milking). 
TABle IV. Total $\beta$ Activity of NeH-NAR Glacier Samples

\begin{tabular}{|c|c|c|c|c|c|c|c|}
\hline \multirow[t]{2}{*}{ Sample } & \multirow{2}{*}{$\begin{array}{l}\text { Depth in } \\
\text { core or } \\
\text { altitude } \\
\mathrm{m}\end{array}$} & \multirow[t]{2}{*}{$\begin{array}{c}\text { Distance } \\
\text { from } \\
\text { accumulation } \\
\text { zone } \\
\mathrm{m}\end{array}$} & \multirow{2}{*}{$\begin{array}{l}\text { Amount } \\
\text { of } \\
\text { water } \\
\mathrm{g}\end{array}$} & \multirow{2}{*}{$\begin{array}{l}T D S \\
\text { ppm }\end{array}$} & \multirow{2}{*}{$\begin{array}{l}\text { Dust } \\
\text { ppm }\end{array}$} & \multicolumn{2}{|c|}{ Net $\beta$ activity } \\
\hline & & & & & & $\mathrm{dpm} / \mathrm{kg}$ water & $\mathrm{dpm} / \mathrm{g}$ dust \\
\hline \multicolumn{8}{|c|}{ Surface samples } \\
\hline 1 & 4150 & 0 & 1745 & 40.5 & 1146 & $10.69 \pm 0.16$ & $264 \pm 4.06$ \\
\hline 2 & 4380 & 500 & 2280 & 44.6 & 289 & $9.88 \pm 0.50$ & $221 \pm 11.3$ \\
\hline 3 & 4320 & 820 & 2120 & 70.8 & 14.1 & $15.66 \pm 1.26$ & $221 \pm 17.8$ \\
\hline 4 & 4203 & 1080 & 1900 & 78.9 & 110 & $6.72 \pm 0.47$ & $85.1 \pm 5.9$ \\
\hline 5 & 4174 & 1200 & 2140 & $\leqslant 117.5$ & NM & $4.39 \pm 0.19$ & $37.4 \pm 1.6$ \\
\hline 6 & 4114 & 1500 & 2150 & $\leqslant 84.5$ & 23.2 & $9.4 \pm 0.88$ & $109 \pm 10.3$ \\
\hline 7 & 4080 & 1730 & 2140 & $\leqslant 156$ & 50 & $8.5 \pm 1.05$ & $54 \pm 6.7$ \\
\hline 8 & 4030 & 2120 & 2220 & $\leqslant 65.2$ & 4.5 & $1.5 \pm 0.03$ & $24 \pm 4.9$ \\
\hline 9 & 3935 & 2350 & 470 & 857 & NM & $20.53 \pm 2.8$ & $24 \pm 3.3$ \\
\hline \multicolumn{8}{|c|}{ Core samples* } \\
\hline 10 & $0-1$ & c. 1000 & 1350 & 27.04 & 74 & $4.43 \pm 0.11$ & $164 \pm 3.95$ \\
\hline 11 & $1-2$ & c. 1000 & 1580 & 10.13 & NM & $0.53 \pm 0.15$ & $52 \pm 14.6$ \\
\hline 12 & $2-3$ & c. 1000 & 1200 & 19.02 & 500 & $25.56 \pm 1.1$ & $1368 \pm 5.9$ \\
\hline 13 & $3-4$ & c. 1000 & 540 & 92.04 & NM & $9.00 \pm 1.0$ & $99.85 \pm 1.0$ \\
\hline 14 & $4-5$ & c. 1000 & 610 & 43.11 & 213 & $7.74 \pm 0.88$ & $83 \pm 9.5$ \\
\hline 15 & $6-7$ & c. 1000 & 1070 & 893.5 & 40 & $138.6 \pm 6.5$ & $155 \pm 7.3$ \\
\hline 16 & $8-9$ & c. 1000 & 1250 & 565.6 & 51 & $82.9 \pm 4.0$ & $146.5+7.2$ \\
\hline 17 & $9-10$ & c. 1000 & 1340 & 492.2 & 50 & $56.1 \pm 3.1$ & $114 \pm 6.3$ \\
\hline
\end{tabular}

* For location of core, see Figure 3.

NM Not measured.

${ }^{210} \mathrm{~Pb}$ activity measured in aliquots taken from samples where ${ }^{32} \mathrm{Si}$ was also measured is given in Table IIa. Since the ${ }^{210} \mathrm{~Pb}$ activity is high, as can be seen from this table, it was measured in a 5 or $10 \%$ fraction of the sample. The water equivalent for ${ }^{210} \mathrm{~Pb}$ was calculated on the basis of the assumption that the efficiency of lead scavenging is the same as that for silica. In two samples, NG-1 and NG-2, there is an uncertainty, as shown in column 2 of Table IIa, in estimating water equivalent for lead samples, since the yield of silica had been low, possibly due to loss of water during scavenging. This uncertainty does not affect the ${ }^{32} \mathrm{Si}$ data given in Table I but it has to be considered for ${ }^{210} \mathrm{~Pb}$ because its carrier was not added to the water before scavenging lead. The counting rates, at saturation, vary from 25 to 94 counts per minute and there is about $1 \%$ statistical error in estimating ${ }^{210} \mathrm{~Pb}$ activity. The error in estimating the quantity of water is therefore more serious. This uncertainty does not occur in other surface samples where small volumes of water were collected and hence these measurements are more reliable.

TABle V. Gamma activity of Neh-NAR Glacier CORE SAMPLeS*

\begin{tabular}{|c|c|c|c|c|c|}
\hline Sample & $\begin{array}{c}\text { Amount } \\
\text { of } \\
\text { water } \\
\mathrm{kg}\end{array}$ & \multicolumn{2}{|c|}{ 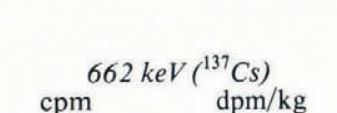 } & \multicolumn{2}{|c|}{ 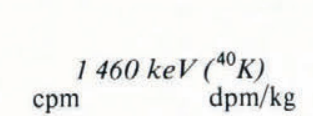 } \\
\hline $\begin{array}{l}10 \\
11 \\
12 \\
13 \\
14 \\
15 \\
16 \\
17\end{array}$ & $\begin{array}{l}1.35 \\
1.58 \\
1.2 \\
0.64 \\
0.61 \\
1.07 \\
1.25 \\
1.34\end{array}$ & $\begin{array}{l}0.307 \\
0.074 \\
1.56 \\
0.31 \\
0.10 \\
0.172 \\
0.177 \\
0.048\end{array}$ & $\begin{array}{l}1.27 \pm 0.43 \\
0.26 \pm 0.37 \\
7.3 \pm 0.5 \\
3.34 \pm 1.5 \\
0.92 \pm 0.77 \\
0.90 \pm 0.63 \\
0.79 \pm 0.68 \\
0.2 \pm 0.37\end{array}$ & $\begin{array}{l}<0.05 \\
<0.05 \\
\sim 0.08 \\
\sim 0 \\
0.1 \\
0.17 \\
0.14 \\
0.17\end{array}$ & $\begin{aligned}<5 \\
<5 \\
\sim \overline{43} \\
\sim \\
\quad 23.42 \pm 16 \\
22.96 \pm 13 \\
16.23 \pm 7 \\
19.08 \pm 7\end{aligned}$ \\
\hline
\end{tabular}

* For location of core, see Figure 3. 
The total $\beta$ activity in the samples ranged from 1 to $20 \mathrm{dpm} / \mathrm{kg}$ (Table IV). As mentioned earlier, there is some uncertainty in the results given in this table due to self-absorption correction because first the counting efficiency and absorption coefficient $\left(0.364\right.$ and $0.0283 \mathrm{~cm}^{2} / \mathrm{g}$, respectively) were taken to be the same as that for ${ }^{210} \mathrm{Bi}$. This may not be true. Secondly, there may be additional absorption due to some moisture present. These effects, are not serious and the values given in Table III can be assumed to be correct within $\pm 20 \%$.

The results on core samples are given in Tables III, IV, and V. Two of the samples, 10 and 12 , were measured for decay of ${ }^{210} \mathrm{Bi}$ separated from ${ }^{210} \mathrm{~Pb}$ as well as by following in situ growth of ${ }^{210} \mathrm{Bi}$ from ${ }^{210} \mathrm{~Pb}$, from which ${ }^{210} \mathrm{Bi}$ was initially removed. Both of them yield values which are in close agreement. The core data are also shown in Figure 4. The $\gamma$ activity shows a signal of $0.66 \mathrm{MeV}$ (Table V). Although this can be attributed to ${ }^{137} \mathrm{Cs}$, the identification must remain

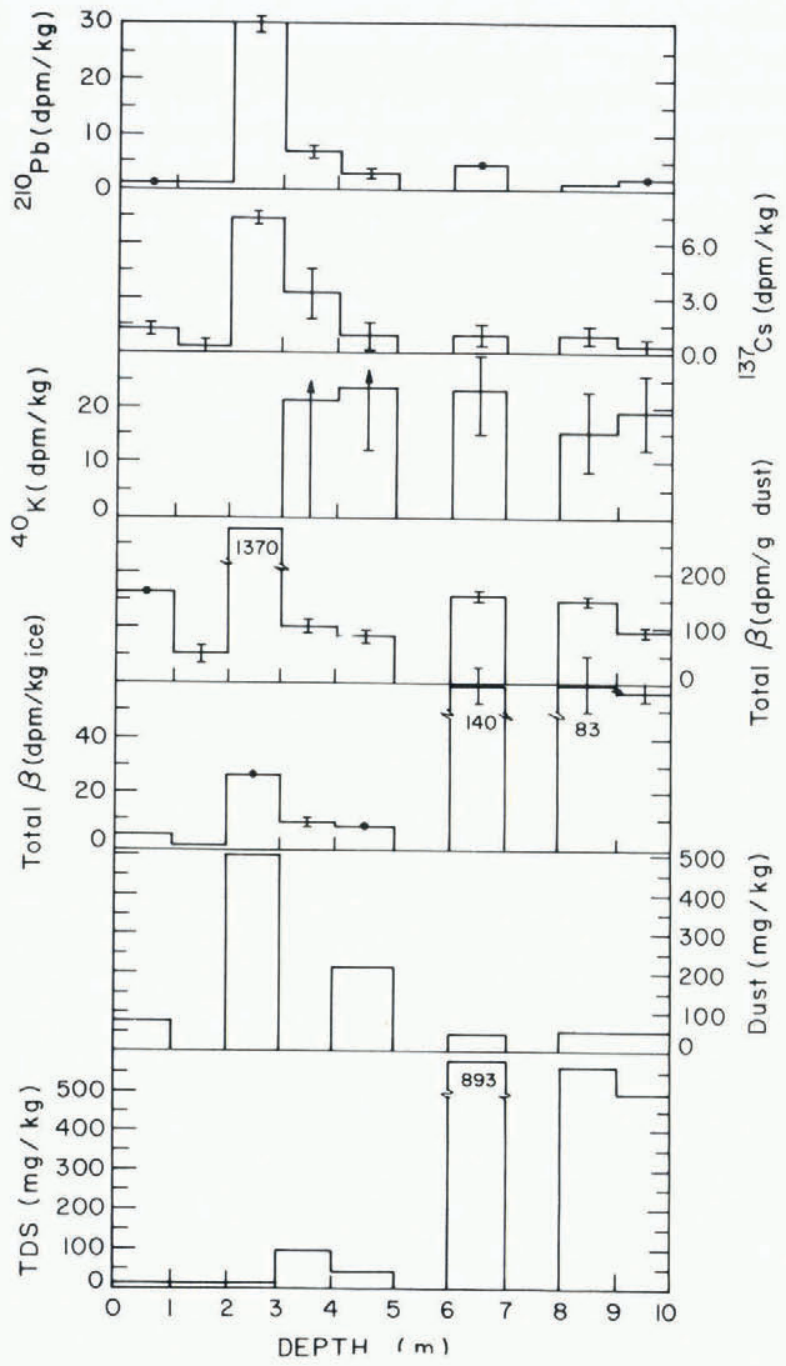

Fig. 4. Depth profile of ${ }^{210} \mathrm{~Pb},{ }^{137} \mathrm{Cs},{ }^{40} \mathrm{~K}$, total $\mathrm{\beta}$ activity (dpm/ $\mathrm{kg}$ ice and dpm/g dust), TDS, and dust content in the Neh-nar core samples. 
tentative because the signal is marginal except in one case and not quite specific; further experiments are necessary to confirm it. The main features of these data can be summed up as follows:

1. The ${ }^{210} \mathrm{~Pb}$ activity in the fresh snow (1976) from the accumulation zone is about $4.5 \mathrm{dpm} / \mathrm{kg}$. This is similar to the activity observed elsewhere in fresh precipitation (Crozaz and Langway, 1966; Lal and others, 1979; Bhandari, unpublished). It decreases to $\leqslant 0.3 \mathrm{dpm} / \mathrm{kg}$ within $500 \mathrm{~m}$ of the glacier head. Although samples are limited in number, based on ${ }^{210} \mathrm{~Pb}$ in surface samples, five regions (A, B, C, D, and E) can broadly be classified as shown in Figure 3: (i) above $4300 \mathrm{~m}$ altitude having values of $\geqslant 4 \mathrm{dpm} / \mathrm{kg}$; (ii) between 4200 and $4350 \mathrm{~m}$ with values $<0.9 \mathrm{dpm} / \mathrm{kg}$; (iii) between 4130 and $4200 \mathrm{~m}$ with values between 2 and $4 \mathrm{dpm} / \mathrm{kg}$; (iv) between 4000 and $4100 \mathrm{~m}$ with values below $0.6 \mathrm{dpm} / \mathrm{kg}$; and (v) below $4000 \mathrm{~m}$ to the snout with values between 1 and $2 \mathrm{dpm} / \mathrm{kg}$. These five zones, with alternating high and low values of ${ }^{210} \mathrm{~Pb}$, seem to be a unique feature of this glacier (Fig. 5), in contrast with a decreasing activity observed in Alpine glaciers (Crozaz, 1967).

2. There is a well-defined peak in ${ }^{210} \mathrm{~Pb}$, total $\beta$ activity, and dust content at $2-3 \mathrm{~m}$ depth in the core (Fig. 4). The ${ }^{210} \mathrm{~Pb}$ activity here of $32 \pm 3 \mathrm{dpm} / \mathrm{kg}$ is about four times higher than expected in fresh precipitation.

3. In the deeper sections of the core, ${ }^{40} \mathrm{~K}$ activity is higher than in the upper strata but ${ }^{40} \mathrm{~K}$ activity is not associated with ${ }^{210} \mathrm{~Pb}$ or ${ }^{137} \mathrm{Cs}$.

4. The total dissolved salts (TDS) also increase with depth, being correlated with potassium content.

5. The ${ }^{32} \mathrm{Si}$ activity ranges between $0.37 \mathrm{dpm} /$ ton in fresh snow of 1976 from near the accumulation zone to $0.18 \mathrm{dpm} /$ ton in the snout ice sample (Fig. 2). The snout water has a value of $0.42 \mathrm{dpm} / \mathrm{ton}$, higher than in any other sample.

\section{DISCUSSION}

The results on the distribution of radioactivity in the core and surface samples can be used to understand the behaviour of Neh-nar Glacier in the past on the time-scale of a few decades to a few centuries, over which the activities of ${ }^{210} \mathrm{~Pb}$ and ${ }^{32} \mathrm{Si}$ are sensitive. We first discuss the expected natural levels of these two isotopes and then the results from the core and surface samples.

\section{Natural fall-out levels of ${ }^{32} \mathrm{Si}$ and ${ }^{210} \mathrm{~Pb}$}

For the purpose of dating ice samples, we ought to know the average fall-out values of natural ${ }^{32} \mathrm{Si}$ and ${ }^{210} \mathrm{~Pb}$ and should be able to exclude any bomb contribution. The annual fall-out value is highly variable from year to year. The fresh (1976) snow (NG-2) value of $0.37 \mathrm{dpm} /$ ton for ${ }^{32} \mathrm{Si}$, thus, cannot be taken as the average for the last 1000 years. The fall-out values determined at other locations (Dansgaard and others, 1966; Lal and others, 1979) vary between 0.3 and $1.1 \mathrm{dpm} /$ ton. The fall-out at Pathankot (lat. $32^{\circ} 14^{\prime} \mathrm{N}$.) between 1961 and 1968 varied between 0.27 and $0.7 \mathrm{dpm} / \mathrm{ton}$, and at Ludhiana (lat. $30^{\circ} 56^{\prime} \mathrm{N}$.) it was $0.38 \mathrm{dpm} /$ ton in 1970 (Lal and others, 1979). However, in view of the bomb contribution, Lal and others (1979) adopted a value of $0.3 \pm 0.1 \mathrm{dpm} /$ ton for the Indian sub-continent. The fall-out in Denmark is, however, around $1 \mathrm{dpm} /$ ton with values going up to $4.7 \mathrm{dpm} /$ ton for peak periods of nuclear fallout. Furthermore, Neh-nar Glacier lies at lat. $34^{\circ} \mathrm{N}$., which is close to the region where a transition in fall-out pattern takes place; between lat. $0^{\circ}$ to $30^{\circ}$ the ${ }^{32} \mathrm{Si}$ activity is around $0.3 \mathrm{dpm} /$ ton, whereas north of lat. $40^{\circ}$ it is $0.95 \mathrm{dpm} /$ ton (Lal and Peters, 1967). A small change in atmospheric structure or circulation pattern may thus change the ${ }^{32} \mathrm{Si}$ value in precipitation at the Neh-nar Glacier site. Neglecting such variations, a value of $0.5 \pm 0.1 \mathrm{dpm} /$ ton must represent 


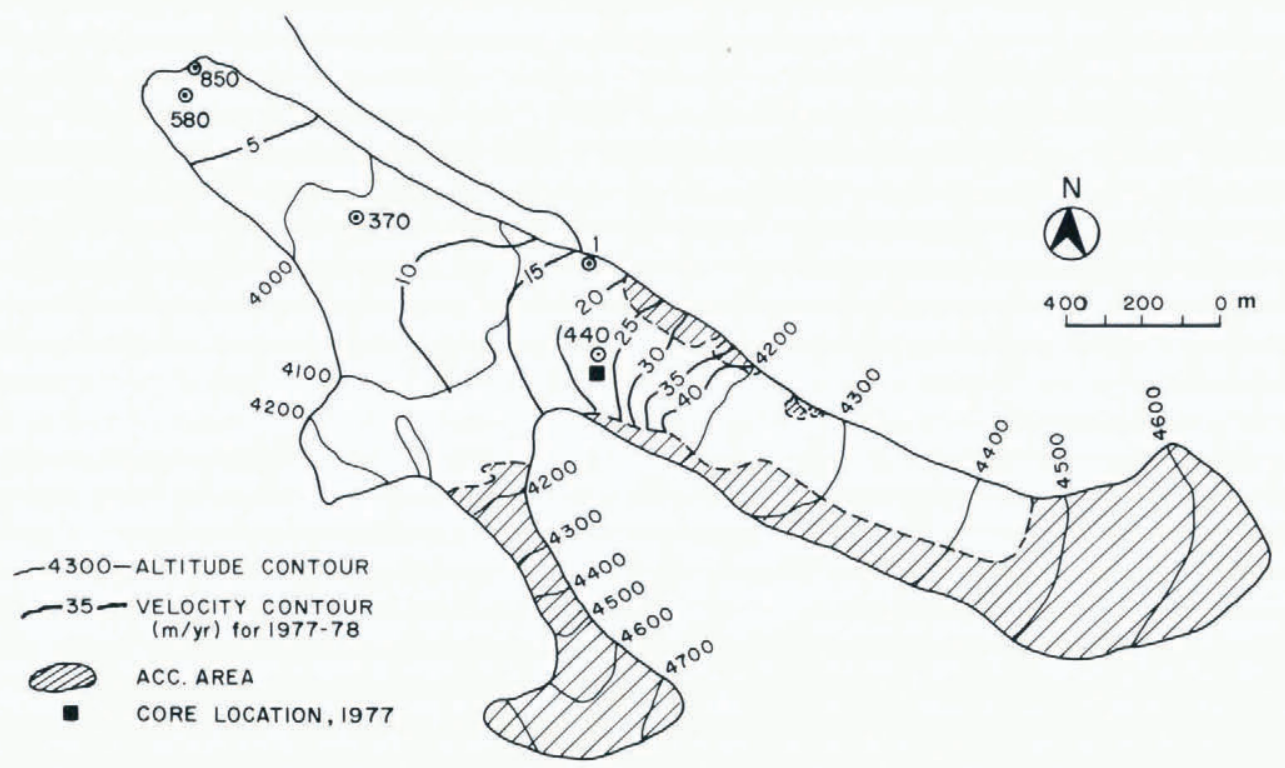

Fig. 5. Model ages of surface ice samples based on ${ }^{32} \mathrm{Si-}{ }^{210} \mathrm{~Pb}$ measurements. The contours show velocity in $\mathrm{m} /$ year for 1977-78 as measured by the GSI stake experiment.

the long-term average natural fall-out value for ${ }^{32} \mathrm{Si}$ at the Neh-nar Glacier site, in view of the above considerations. Here we adopted the value of $0.5 \mathrm{dpm} /$ ton for the purpose of calculating the ages of ice samples.

There is also evidence for production of ${ }^{32} \mathrm{Si}$ in nuclear tests. However, this production has been estimated to be marginal, confined to a brief period of one or two years, and here we ignored the bomb contribution. For ${ }^{210} \mathrm{~Pb}$, the 1976 fresh-snow value (NG-2) is $4.2 \mathrm{dpm} / \mathrm{kg}$ but a value of $4.7 \mathrm{dpm} / \mathrm{kg}$ for sample 2 has been obtained. In view of the work of Joshi and others (1969), in which fall-out at various nearby locations was measured, we assumed here a value of $8 \mathrm{dpm} / \mathrm{kg}$ for the average fall-out of ${ }^{210} \mathrm{~Pb}$ at the Neh-nar Glacier site over the last 100 years.

\section{Radioactive horizon in the core section}

The $0-1 \mathrm{~m}$ section of the core shows an activity of $\leqslant 1 \mathrm{dpm} / \mathrm{kg}$, corresponding to an age of $\geqslant 100$ years. Such a large age is expected in the ablation zone. However, between 2 and $5 \mathrm{~m}$ (Table III) the activity levels are much higher, ranging between 3 and $35 \mathrm{dpm} / \mathrm{kg}$.

The natural levels of ${ }^{210} \mathrm{~Pb}$ in precipitation at lat. $34^{\circ} 06^{\prime} \mathrm{N}$. (Srinagar) between 1962 and 1965 were between 6 and $8 \mathrm{dpm} / \mathrm{kg}$ (Joshi and others, 1969), and the same is true for other locations. We now discuss the observation of high ${ }^{210} \mathrm{~Pb}$ and its correlation with fission-produced ${ }^{137} \mathrm{Cs}$, dust, and total $\beta$ activity between 2 and $3 \mathrm{~m}$ in the core. One possibility is their origin in nuclear tests. However, we must consider and exclude other possibilities before this horizon is attributed to nuclear debris. First, although bomb production of ${ }^{210} \mathrm{~Pb}$ has been considered likely (Jaworowski and others, 1975), there is no clear indication of it in air or precipitation samples as indicated by the following observations. Bhandari (unpublished) found only marginally high values of ${ }^{210} \mathrm{~Pb}$ in the lower stratosphere after the peak explosion era (1964-65) but during the same period rain water in Bombay and other stations in India showed near-natural levels. Georgieva and Dimchev (1977) have observed a large altitude dependence in specific activity of ${ }^{210} \mathrm{~Pb}$ and fission products in Bulgarian precipitation. The 1978 precipitation samples collected at Gara and Changme Khangpu Glaciers, situated in northern and eastern Himalaya, show activity 
levels of only $\leqslant 8 \mathrm{dpm} / \mathrm{kg}$ (Bhandari and others, unpublished). Jaworowski and others (1975) have determined ${ }^{210} \mathrm{~Pb},{ }^{137} \mathrm{Cs},{ }^{226} \mathrm{Ra}$, and $\mathrm{U}$ in several samples, including the Nepalese Himalaya from 1957 to 1970 . They found that ${ }^{137} \mathrm{Cs}$ and ${ }^{210} \mathrm{~Pb}$ activity peaks and troughs occur together. Crozaz (1967) found no evidence for bomb-produced ${ }^{210} \mathrm{~Pb}$ in Greenland, Antarctic, and Alpine glaciers. Secondly, volcanic eruptions make an additional contribution to ${ }^{210} \mathrm{~Pb}$. However, the amount of volcanic dust should be correlated with potassium content and ${ }^{40} \mathrm{~K}$ may serve as a monitor of the volcanic component. Thirdly, the Himalayan glaciers have a rather high content of dust which is non-volcanic in origin. The dissolved salt content in surface and core samples varies from $10 \mathrm{mg} / \mathrm{kg}$ to about $1 \mathrm{~g} / \mathrm{kg}$ water, and the (undissolved) dust content from less than $10 \mathrm{mg}$ to $500 \mathrm{mg} / \mathrm{kg}$. Although, in general, the ${ }^{210} \mathrm{~Pb}$ activity is found not to be proportional to dust content (Table IV), sample 12 (Table III) containing the highest ${ }^{210} \mathrm{~Pb}$ activity has also the highest dust content of $500 \mathrm{mg} / \mathrm{kg}$. Thus, it is important to estimate the ${ }^{210} \mathrm{~Pb}$ contribution from the local dust. Finally, the natural source of ${ }^{210} \mathrm{~Pb}$ is atmospheric radon and its concentration levels can be influenced by the atmospheric circulation pattern. Evidence has been found for concurrent changes in ${ }^{210} \mathrm{~Pb},{ }^{137} \mathrm{Cs},{ }^{226} \mathrm{Ra}$, and U isotopes (Jaworowski and others, 1975), which suggests that their deposition is influenced by atmospheric circulation. Similar correlations can be clearly seen from Figure 4 where ${ }^{210} \mathrm{~Pb},{ }^{40} \mathrm{~K}$, total $\beta$ activities and TDS, and dust content, are plotted as a function of depth in the core sections. This correlation also exists for the $0.66 \mathrm{MeV}$ signal which is possibly due to ${ }^{137} \mathrm{Cs} .{ }^{210} \mathrm{~Pb}$, total $\beta$ activity $(\mathrm{dpm} / \mathrm{g})$, and dust seem to correlate well with each other, all showing a maximum at 2-3 m depth. On the other hand, K and TDS content also correlate with each other but not with the tracers mentioned above or with the dust content.

If this horizon is due to nuclear debris, it is difficult to identify the nuclear explosion which may have been responsible for it. Jaworowski and others (1978) suggested a large injection of ${ }^{210} \mathrm{~Pb}$ from the 27 June 1973 Chinese explosion in which advanced fusion devices were used. Before and in the early 1960's several high-yielding nuclear tests were carried out by the USSR and USA. The absence of young ice above this radioactive horizon excludes the possibility that the ice is gradually accumulating at this site since the radioactive debris was deposited. In fact, the overlying layers of ice are older than 100 years, as pointed our earlier, and this calls for a complicated mechanism of accumulation and transport. It may be mentioned that the coring site is close to the equilibrium line but is located in the ablation zone (Fig. 3). Therefore, the presence of this radioactive horizon is not understood at present. Additional work on nearby bore holes is in progress to obtain further information on this aspect. Notwithstanding the production of ${ }^{210} \mathrm{~Pb}$ in nuclear debris, all samples below $6 \mathrm{~m}$ show negligible activity of ${ }^{210} \mathrm{~Pb}$ and are at least 100 years old.

\section{Radioactivity in surface samples}

The distribution of ${ }^{32} \mathrm{Si}$ and ${ }^{210} \mathrm{~Pb}$ activity is shown in Figures 2 and 3, respectively. The annual and the perennial channels are also marked on these maps. It is seen that the movement of ice, particularly in the lower half of the glacier, is very complicated because ice from different accumulation zones and the tributary mixes here.

In the ${ }^{210} \mathrm{~Pb}$ distribution we find several zones, as noted earlier, of high and low activity, whereas the ${ }^{32} \mathrm{Si}$ activity is rather uniform, except near the snout. Based on the observed ${ }^{32} \mathrm{Si}$ and ${ }^{210} \mathrm{~Pb}$ activity and the adopted values of average specific activity in the fall-out $\left({ }^{32} \mathrm{Si}=0.5 \mathrm{dpm} / \mathrm{ton},{ }^{210} \mathrm{~Pb}=8 \mathrm{dpm} / \mathrm{kg}\right)$, we can calculate the "apparent" ages of ice samples which give the time elapsed since precipitation if the system has been a closed one. These are given in Tables I and II, respectively, for ${ }^{32} \mathrm{Si}$ and ${ }^{210} \mathrm{~Pb}$. These range up to 450 years for ${ }^{32} \mathrm{Si}$ and $\approx 100$ years for ${ }^{210} \mathrm{~Pb}$. However, as noted earlier, the two "apparent" ages in the samples are not concordant, indicating that the assumption of a closed system is not valid. Part of the discrepancy may be due to the sampling problem, in which fresh melt waters may have mixed with the local ice during sample collection. Alternatively, it could also be a result of natural 
mixing of fresh and old waters in the glacier. Since the behaviour of temperate glaciers, particularly in the Himalaya, where high altitude, high wind currents, and variable temperatures play a dominant role, melting and refreezing cannot be ruled out. In any case, if we consider a simplified two-component model, one component referring to "fresh" ice ( $<10$ years) and the second to "old" ice ( $>100$ years) on the basis of ${ }^{210} \mathrm{~Pb}$ half life, we can correct for both the natural mixing and that during sampling, and obtain the real age of the glacier. The high ${ }^{210} \mathrm{~Pb}$ horizon seems to be contained around a depth of $2-3 \mathrm{~m}$ just below the equilibrium line. It may be buried much deeper at higher altitudes and may have ablated away down-stream. Therefore, it is not necessary to consider this horizon in the model, but the effects of alternating zones are automatically taken into account in the mixing model.

Using the two-component model, the correction for the fresh-water contribution $\left(C_{\mathrm{fw}}\right)$ is applied as follows:

$$
C_{\mathrm{fw}}=A_{210} / F_{210}
$$

where $A$ and $F$ refer to the observed activity in a sample and the fall-out value. The corrected ${ }^{32} \mathrm{Si}$ activity $\left(A_{\mathrm{C} 32}\right)$ is then given by

$$
A_{\mathrm{C} 32}=A_{32}-F_{32} C_{\mathrm{fw}} .
$$

Subscripts 210 and 32 are used for ${ }^{210} \mathrm{~Pb}$ and ${ }^{32} \mathrm{Si}$, respectively.

The age, $T$, of the sample is calculated based on this value from the relation:

$$
A_{\mathrm{C} 32}=F_{32} \mathrm{e}^{-\lambda_{32} T} \text {. }
$$

Assuming $F_{32}=0.5 \mathrm{dpm} /$ ton and $F_{210}=8 \mathrm{dpm} / \mathrm{kg}$ as discussed earlier, the value of $T$ so obtained is taken to be the correct age of the sample. The fresh-water contribution is estimated, from ${ }^{210} \mathrm{~Pb}$ values, to be $14-30 \%$ for various samples. If the actual fresh-water contribution is less than that determined here, the ages will represent upper limits to the true age of the sample. Thus the uncorrected (or apparent) and corrected ${ }^{32} \mathrm{Si}$ ages represent the range within which the true age must lie.

The corrections are applied to all samples except fresh snow sample NG-2, which is known to have an age of 1 year. The ${ }^{32} \mathrm{Si}$ activity corrected for ${ }^{210} \mathrm{~Pb}$ and the corrected ${ }^{32} \mathrm{Si}$ ages are given in Table VI.

The two-component model ages range up to 850 years. The age distribution is also shown in Figure 5. These ages must be discussed within the limitation of this model. In reality, ices of all ages mix but it is difficult to consider such a complex situation based on only two tracers. Also, the fluctuations in specific activity of tracers in fall-out have not been taken into account in these deductions, and there is some uncertainty in the value of the decay constant of ${ }^{32} \mathrm{Si}$. If the actual fall-out value is $0.6 \mathrm{dpm} / \mathrm{ton}$, the corrected age of the snout ice will increase to 1080 years

\begin{tabular}{|c|c|c|c|c|c|c|c|}
\hline Code & $\begin{array}{l}\text { Nature of } \\
\text { sample }\end{array}$ & $\underset{\mathrm{m}}{\text { Altitude }}$ & $\begin{array}{c}\text { Distance } \\
\text { from } \\
\text { accumulation } \\
\text { zone } \\
\mathrm{m}\end{array}$ & $\begin{array}{c}{ }^{32} \mathrm{Si} \\
\mathrm{dpm} / \mathrm{ton}\end{array}$ & $\begin{array}{c}{ }^{210} \mathrm{~Pb} \\
\mathrm{dpm} / \mathrm{kg}\end{array}$ & $\begin{array}{c}\text { Corrected } \\
{ }_{32} \mathrm{Si} \\
\mathrm{dpm} / \mathrm{ton}\end{array}$ & $\begin{array}{c}\text { Corrected } \\
{ }_{32} \text { Si age } \\
\text { years }\end{array}$ \\
\hline NG-2 & Fresh snow & 4150 & 0 & $0.37 \pm 0.03$ & 4.2 & $0.37^{(\mathrm{a})}$ & $1^{\text {(a) }}$ \\
\hline NG- & & 4140 & 1300 & $0.33 \pm 0.03$ & 2.43 & 0.18 & 440 \\
\hline NG-3 & Ice & 4020 & 2000 & $0.36 \pm 0.03$ & 2.1 & 0.23 & 370 \\
\hline NG-4 & Snout water & 3920 & 2850 & $0.42 \pm 0.04$ & 1.12 & 0.35 & 160 \\
\hline NG-5 & Snout ice & & & & & & \\
\hline & of tributary & 3920 & 1850 & $0.21 \pm 0.04$ & 1.27 & 0.13 & 580 \\
\hline NG-6 & Snout ice & 3920 & 2750 & $0.18 \pm 0.03$ & 1.75 & 0.07 & 850 \\
\hline
\end{tabular}
compared with 850 years based on the value of $0.5 \mathrm{dpm} /$ ton.

TABLE VI. ${ }^{32} \mathrm{Si}$ AND ${ }^{210} \mathrm{~Pb}$ ACTIVITY IN SURFACE SAMPLES AND ICE AGES

(a) No correction has been applied to this sample. For explanation see text. 


\section{Chronology of Neh-nar Glacier}

The model ages calculated above indicate the time taken for the ice to reach the sampling site from the time of precipitation. We consider here the significance of the ages of some of the samples. Sample NG-1 was collected at an altitude of $4140 \mathrm{~m}$ and this site is fed by ice from the main accumulation zone; there are no contributions from the tributaries. The annual rate of ice movement around the altitude of $4150 \mathrm{~m}$ is $20 \mathrm{~m} /$ year increasing upwards (Fig. 5), as measured by the movement of stakes (Vohra and others, unpublished), and at this rate the ice must take only $<75$ years to move a distance of $1.5 \mathrm{~km}$ from the accumulation zone. Thus the high ${ }^{32} \mathrm{Si}$ age of 440 years indicates that the ice spends a considerable time in the accumulation zone before it moves along the glacier. This period should be of the order of 300 years but more highaltitude sampling should be done to determine this value. Sample NG-2 was collected from near the subsidiary accumulation zone, which partly feeds the site where NG-3 was collected. The age of NG-3 of about 370 years is thus understood in terms of multiple sources where older ice from the main accumulation zone is continually mixed with young ice from a subsidiary accumulation zone. Sample NG-4, which represents the melt water of the whole glacier at the snout, gives a much younger age, c. 150 years, and thus, although it is derived from ice of all ages, a large fraction of this water seems to be relatively young. Alternatively, it is also possible that the specific activity of the melt water increases due to evaporation losses during its movement along the glacier surface. Sample NG-5, representing snout ice of the tributary, gives an age of 580 years, again giving an average rate of movement of $c .3 \mathrm{~m} / \mathrm{year}$. The snout sample NG-6, which represents the snout ice of the main glacier body, gives an age of 850 years, thus giving an average rate (after correcting for the time spent in the accumulation zone) of about $4 \mathrm{~m} /$ year between an altitude of $4300 \mathrm{~m}$ and the snout. These are only approximate estimates in view of the uncertainties discussed above, particularly due to multiple accumulation zones.

The most reliable rate of movement of the ice can be calculated for the lower glacier by comparing the ages of samples NG-3 (altitude $4020 \mathrm{~m}$ ) and the terminus which is not affected by the complicated dynamics of accumulation zones. This rate turns out to be $c .2 \mathrm{~m} /$ year.

The measured annual velocity contours for $1977-78$ based on the GSI stake experiment are shown in Figure 6 . The rates vary from about $40 \mathrm{~m} /$ year at an altitude of about $4200 \mathrm{~m}$ to $5 \mathrm{~m} /$ year at $3950 \mathrm{~m}$. The measured rates are about $2.65 \mathrm{~m} /$ year near the snout. The rate measured here of $2 \mathrm{~m} /$ year, which is an average over the past 500 years, is comparable with this annual rate of movement.

\section{ACKNOWLEDGEMENTS}

We thank Dr D. I. Bhatt, Dr H. R. Prabhakara, Dr S. Desai, Mr K. M. Suthar and Mr D. Chandrasekhar for assistance at various stages of this work. Our appreciation is due to several colleagues at the GSI, especially S/Shri R. K. Singh, A. R. Sharma, and D. Srivastava for active participation in the field work, to Dr G. S. Murty for information about nuclear tests, to Dr B. Sahai for satellite imagery, and to Professors S. Krishnaswami and B. L. K. Somayajulu for valuable comments. We are grateful to Professor K. R. Ramanathan and Shri V. S. Krishnaswamy, Director General, GSI, for encouragement to undertake this programme.

MS. received 2 January 1980 and in revised form 8 May 1980

\section{REFERENCES}

Bhandari, N. Unpublished. Atmospheric processes based on radioactive tracers. [Ph.D. thesis, University of Bombay, 1965.]

Bhandari, N., and others. 1979. Groundwater velocity around Pokhran and confinement of radioactivity produced by the nuclear explosion, by N. Bhandari, P. S. Datta, and S. K. Gupta. (In Gupta, S. K., and Sharma, P., ed. Arid zone hydrology. New Delhi, Today and Tomorrow's Printers, p. 127-35.) 
Bhandari, N., and others. Unpublished. Radiometric chronology of some Himalayan glaciers based on ${ }^{32} \mathrm{Si}$ and ${ }^{210} \mathrm{~Pb}$, by N. Bhandari, D. I. Bhatt, V. N. Nijampurkar, and C. P. Vohra. [Paper presented at the Workshop on Isotopes in Hydrology, Hyderabad, 1980.|

Clausen, H. B. 1973. Dating of polar ice by ${ }^{32}$ Si. Journal of Glaciology, Vol. 12, No. 66, p. 411-16.

Crozaz, G. 1967. Datation des glaciers par le plomb-210. (In Radioactive dating and methods of low-level counting. Proceedings of a symposium organized by the International Atomic Energy Agency in co-operation with the Joint Commission on Applied Radioactivity (ICSU) and held in Monaco, 2-10 March 1967. Vienna, International Atomic Energy Agency, p. 385-93. (Proceedings Series.))

Crozaz, G., and Langway, C. C., jr. 1966. Dating Greenland firn-ice cores with Pb-210. Earth and Planetary Science Letters, Vol. 1, No. 4, p. 194-96.

Dansgaard, W., and others. 1966. Evidence for bomb-produced silicon 32, by W. Dansgaard, H. B. Clausen, and A. Aarkrog. Journal of Geophysical Research, Vol. 71, No. 22, p. 5474-77.

Elmore, D., and others. 1980. Half-life of ${ }^{32} \mathrm{Si}$ with tandem-accelerator mass spectrometry, by D. Elmore [and 7 others]. Physical Review Letters, Vol. 45, No. 8, p. 589-92.

Georgieva, L., and Dimchev, T. 1977. Opredeleniye niznikh kontsentratsiy ${ }^{90} \mathrm{Sr},{ }^{137} \mathrm{Cs}, \mathrm{i}^{210} \mathrm{~Pb}$ v osadkakh na territorii bolgarii [Determination of low concentrations of ${ }^{90} \mathrm{Sr},{ }^{137} \mathrm{Cs}$, and ${ }^{210} \mathrm{~Pb}$ in fallout on the Bulgarian territory]. (In Povinec, P., and Usačev, S., ed. Low-radioactivity measurements and applications. Proceedings of the international conference, the High Tatras, CSSR, 6-10 October 1975. Bratislava, Slovenské Pedagogické Nakladatel'stvo, p. 507-09.)

Goldberg, E. D. 1963. Geochronology with lead-210. (In Radioactive dating. Proceedings of the symposium on radioactive dating held by the International Atomic Energy Agency in co-operation with the Joint Commission on Applied Radioactivity (ICSU) in Athens, 19-23 November 1962. Vienna, International Atomic Energy Agency, p. 121-30. (Proceedings Series.))

Jaworowski, Z., and others. 1975. Stable and radioactive pollutants in a Scandinavian glacier, by Z. Jaworowski, J. Bilkiewicz, and E. Dobsz. Environmental Pollution, Vol. 9, No. 4, p. 305-15.

Jaworowski, Z., and others. 1978. Lead 210 from nuclear explosions in the environment, by Z. Jaworowski, L. Kownack, K. Grotowski, and K. Kwiatkowski. Nuclear Technology, Vol. 37, No. 2, p. 159-66.

Joshi, L. U., and others. 1969. Measurement of lead-210 in surface air and precipitation, by L. U. Joshi, C. Rangarajan, and S. Gopalakrishnan. Tellus, Vol. 21, No. 1, p. 107-12.

Kutschera, W., and others. 1980. Measurement of the ${ }^{32} \mathrm{Si}$ half-life via accelerator mass spectrometry, by W. Kutschera [and 8 others]. Physical Review Letters, Vol. 45, No. 8, p. 592-96.

Lal, D., and Peters, B. 1967. Cosmic ray produced radioactivity on the Earth. (In Flügge, S., ed. Handbuch der Physik, Bd. 46/2. Berlin, etc., Springer-Verlag, p. 551-612.)

Lal, D., and others. 1970. Silicon-32 hydrology, [by] D. Lal, V. N. Nijampurkar, S. Rama. (In Isotope hydrology 1970. Proceedings of a symposium on use of isotopes in hydrology held by the International A tomic Energy Agency in co-operation with the United Nations Educational, Scientific and Cultural Organization in Vienna, 9-13 March 1970. Vienna, International Atomic Energy Agency, p. 847-68. (Proceedings Series.))

Lal, D., and others. 1979. Annual fallout of ${ }^{32} \mathrm{Si},{ }^{210} \mathrm{~Pb},{ }^{22} \mathrm{Na},{ }^{35} \mathrm{~S},{ }^{7} \mathrm{Be}$ in rains in India, by D. Lal, V. N. Nijampurkar, G. Rajagopalan, and B. L. K. Somayajulu. Proceedings of the Indian Academy of Sciences, Vol. 88A, Pt. 2, No. 1, p. $29-40$.

Navaratna, M. R. Unpublished. Studies on metal complexes of Dalzin. [M.Sc. thesis, University of Bombay, 1974.]

Nijampurkar, V. N. Unpublished. Dating of groundwaters by silicon-32. [Ph.D. thesis, University of Bombay, 1974.]

Nijampurkar, V. N., and Bhandari, N. Unpublished. Dating of glaciers with environmental radioisotopes. [Paper presented at an international workshop on ice, snow, and glaciers held at Manali, March 1977.]

Ramanna, R. 1975. On some new possibilities of peaceful uses of atomic energy. Chemical Engineering World, 1974 Annual, p. 37-42, 45-46, 49-54.

Vohra, S., K., and others. Unpublished. Report on the Panjatarni glacier expedition, by S. K. Vohra, V. Krishnan, C. S. Pathak, and R. A. Tiwari. [Unpublished reports, Glaciology Division, Geological Survey of India, 1975, 1976, 1977.1

\section{Postscript}

Since this paper was written, the half life of ${ }^{32} \mathrm{Si}$ has been revised to $105 \pm 18$ years by Elmore and others (1980) and Kutschera and others (1980), as compared to 300 years used in this paper.

Also, the fall-out value of ${ }^{32} \mathrm{Si}$ appears to be closer to $0.7 \mathrm{dpm} /$ ton as compared to $0.5 \mathrm{dpm} /$ ton adopted in this paper. These new parameters yield a snout age of 500 years and an average glacier flow velocity of $\approx 6 \mathrm{~m} /$ year. 